\title{
Four Narratives and the Enigma of Alterity
}

\author{
Etienne Rassendren*
}

\begin{abstract}
In this article, the author intends to explore the concept of alterity as otherness through an analysis of four highly differentiated narratives drawn from varied textual sources. The paper argues that alterity is depicted in four different and fluid meanings, namely those of separation, difference, assimilation and co-option, constituting enigmas of alterity. In conclusion, the author comments on the cultural-political process, by which these enigmatic constructs are produced and identifies and explains coercion and consent as the hegemonic impetus for its unfolding presence in current cultural-politics.
\end{abstract}

Keywords: Alterity and Otherness, Enigmas of Alterity, Assimilation and Co-option

\section{Introduction}

Alterity is but the function of otherness (Ashcroft, Griffiths \& Tiffin, 1989, p. 53); and its politics is played out between the privileged status of the self and the disempowered position of the other. Thus, alterity as both idea and practice is embedded in the relations between domination and subordination and hence is about power and its implications for culture and practice. The subjectivity ${ }^{1}$ of power, its very ontology ${ }^{2}$, drives the transaction between self and other, which in turn produces the enigma of alterity. Thus, the ontology that marks difference, is at the centre of the politics of alterity that veers between the meanings of separation, difference, assimilation and co-option.

*St Joseph's College, Bengaluru, India; erassendren@gmail.com 
One can break down this philosophical abstraction-namely alterity -into specific characteristics so that the differing dynamics of emergent cultural-politics might be conceptualised. In the current social context, discourse and practice converge to establish cultural formations and projects (Williams, 1977, p. 2 \& p. 55); and both depend on literal and symbolic power for their functioning. Hence notions of civilisation are dependent on what is perceived as uncivilised or de-civilised; majority power is determined by the vulnerability and aggressiveness of assumed minority attitudes. For instance, compulsory heterosexuality is premised on the rejection of other sexualities. Hence all selves and subjectivities emanating from these power dynamics depend on differing forms of otherness.

To extend the notion further, post-enlightenment Europe thought it was a superior civilization to the despotic orient (Said, 1979, p. 32), stereotyping the Orient as lascivious and backward, while archetyping Europe as advanced and moral. Such inter-play between cultural archetypes and ideological stereotypes constituted cultural-political othering, whose racism would shame enlightenment's own modernist logic. In antiquity, conqueror and empire enslaved the conquered, and founded imperialism as both idea and practice. Innations today, political and social leadership ruled over their citizens to establish social hierarchies between the powerful and the powerless. By and large varied forms of authority and control structured political power as the self and subject, in relation to the other and otherness. It also defined master and slave, sovereign and citizen, as the subject and object respectively of the political regime too. Hence otherness in any socio-political process is exactly the opposite of self-definition.

In cultural politics, discursive power invokes differing manners of othering. Often, one form of representation suppresses others, while the inter-relations between master-languages and subjugated ones play out their politics interminably; for instance, dominant languages were/are perceived as inherently superior, while nondominant ones were/are inferiorised. This inferior-superior politics omits the role of cultural coercion involved in making such dominance possible. Hence today, and wherever there was British colonialism, English language and its literature often receive 
precedence over other languages, though English is foreign and is assumed to be alienating to non-native users. The subtleties of language function are not accounted for: how language is an image-forming agent that constructs meaning (Wathiong'o, 1986, $\mathrm{p}$. 15) and how that process is locally driven and not universally determined. Hence local languages should supersede foreign languages. Yet the politics of conquest turned this logic upside down.

So also, it was and is with texts, literary or otherwise. The odd and idiosyncratic ones, differentiated at first, were soon absorbed into wider canonicities, the former's resisting tendencies co-opted into greatness. This literary jugglery mimics religious canonical approaches that subtly absorb radical texts into acceptable frames of reformist dissent. Even anti-colonial literatures have distributed their texts dogmatically within their specific anti-colonial paradigms, like colonial literatures, within theirs; so also, with radical social theology absorbed into dogmatic religious canonicity. Thus, the empowering abilities of difference were and are reduced to conformities.

Alterity however began as difference and ended in repetition, when mimicry became assimilative (Bhabha, 2004, p. 122). For instance, cultural nationalisms absorbed native resistances, and reduced cultural specificity into aggressive identity-politics. Alterity was subtly embraced, not as resistance, but as authoritarianism. Often any resisting view or text, a painting, a book, or a song, was recharacterised as original and standard. The classical claimed the popular, insisting that classicality emerged from the popular.

Ideationally, alterity emerged from a certain separation or difference, while such difference could be coerced into assimilation and co-option. It could be argued here therefore that alterity, both its loss and its longing, lived in cultural narratives, that transacted between story and identity, histories and discontinuities.

In this article, the author seeks to explore four differing narratives in order to depict alterity as it functions in contemporary discourse and practice. The authors also argue that there are enigmas to alterity determined by material contexts. In conclusion, I wish to comment on how such enigmas are produced by coercion and 
consent in hegemonic cultural-politics. The paper presents the analysis for convenience into four parts followed by the conclusion

\section{Singing-Song writing and the Literary Canonicity}

In 2016, the Nobel Committee announced a strange winner for its literature Prize. He was Lithuanian-Jewish and his grand-parents migrated to the US during the infamous anti-Semitic 'pogrom' of 1902 in the Russian empire. He was Robert Allen Zimmerman, quite the singer on the block. He dropped out of college in 1960, because he detested institutionalist rigidity. He formed many music bands and desired to inherit the artistic felicity of the dustbowl folk-artist, Woody Guthrie. He wrote songs and sang them alongside the folk ballads he had heard and collected. His songwriting prowess grew into deep, philosophical ensembles, enquiring into the conditions of the world-its discrimination, inequality, racism, poverty and pain. His "Blowin' in the Wind" and "The Times They Are A-Changin'" (Sennero \& Scrutton, World News Oct 13, 2016) became anthems for the civil rights movement of the 1960's. He protested against America's arrogant misadventure in Vietnam. He was "the voice of a generation" (Sennero \& Scrutton, 2016) inspiring youth and social activists alike. He fought censorship, walking out of even the highly acclaimed Ed Sullivan show. He sang "foreign policy songs"(Førland, 1992, p. 339) which were lacerating critiques of America's domination over the world. His feared an impending nuclear "Armageddon" (p. 340).

He was published, and famous for his drawings, songs and scripts. Suddenly he abandoned his name, Zimmermann, in the 1960's and became Bob Dylan. He rejected any reference to the Welsh poet and furtively referred to his mother's origins for rechristening himself; by 1961 however, he accepted that he serendipitously read Dylan Thomas' poetry. Smitten by its rhythmic brilliance, he chose to rename himself and perhaps reshape his life around the welsh poet's empowering folksiness (Shelton, Folk Music Heard on 12Hour Show. The New York Times, July 29, 1961)

Bob Dylan then became an anthropological wonder, known worldwide for his activism. He was aggressively anti-capitalist and 
promoted liberal democracy and freedom. He troubled the political class and the economic elite incessantly. He won prizes, not for literature, for he was anti-canonical, sardonic, even insulting of the ivory-tower system of academia. He turned reclusive, but suddenly became a Nobel laureate. The Oslo committee's citation was revealing: "for having created new poetic expressions within the great American song tradition" (Ellis-Petersen \& Flood, 13October, 2016). Bob Dylan and the Swedish Academy with him landed in controversy. For some, Dylan hardly deserved the honour; and the Nobel committee had not only erred but disappointed (EllisPetersen \& Flood, 2016) book-lovers because it bypassed literary greats such as Ngugi wa' Thiongo, and Philp Roth (Ellis-Petersen \& Flood, 2016).

What was at stake was Bob Dylan's literariness; he was no canonical litterateur. Besides, he was stridently anti-establishment. With declining reading habits, the arrival of visual culture and the consumerist nature of popular culture (Ellis-Petersen \& Flood, 2016) - Bob Dylan became the wrong choice. The real reason, however, was Dylan's lack of literary canonicity.

Literary canonicity came from two sources; one was religion and the other, the "great conversation"(Hutchins, 1957, pp. x1-xxvii). Both religious dogma and elite intellectualism established literary canonicity, by including sometimes the undeserving and leaving out the deserving ones. In so doing, they formulated ideas of civilization and structured imperialism and colonialism. Religious authority showed the way and literary establishment mimicked its protocols in order to establish the great books of literature

As exemplar evidence, the making of the Bible took centuries to accomplish and was also riddled by uncomfortable questions of authenticity. Books once entered were pulled out, and others not acceptable, were entered in. Some of Paul's letters-like to the Hebrews - were kept out because of uncertain authorship (Richard, Religion-Online, 3 September 2016); and St Jerome discovered anomalies between the original Hebrew Tanakh and its Greek retellings in the new testament. Some quotes of apostles as old Testament references were simply absent in the Hebrew scriptures and the Greek Septuagint (Semple, 1965-6, pp. 227-43). Hence such choices were based on untested pietism and not on critical 
discernment, scientific or otherwise. Hence the episteme for choicemaking was dangerously arbitrary, determined by emotional predilections and unreflective craftiness. That apart, the schisms particularly Arianism, added to the hermeneutic challenge over originality. Despite these epistemological questions, a religious canon was established based on current ideology. There was no real epistemological accuracy; there was spiritual mystique and textual felicity. Therefore, canonicity was constructed on the authority, reputation and power of the classifiers/choosers of texts. That, therefore caused dogmatism, which created a doctrinaire approach to religious texts. The biblical canon then became incontestable; it hegemonised critical scholarship and the public dissemination of knowledge. In the secular world, this dogmatism was imitated and became cultural imperialism. Therefore, the subject of the canon, its very ontology, continues to be driven by ideologies of power, of which the so-called "great conversation"(Hutchins, 1957) forms a part.

In secular terms, canonicity was established through "the great conversation"(Hutchins, 1957, pp. xi \& xii). The so-called 'Western World" (p. xi) claimed that the greatness of its culture and knowledge, its philosophy and its literature, emerged from dialogues between great minds. Great books came out of great authors who conversed with each other to produce knowledge and understanding. For the Great Conversation, popular thought and everyday experiences-all lacked meaning, thus relegating those that occupied such routine as mere masses, who deserved the elite to rule them. The imperial paradigm of civilising the uncivilised, or the class-notion of rescuing the masses from ignorance, was central to the value and worth of such a conversation. Hence choicemaking about knowledge, the very epistemology, by which knowledge was signified, was arbitered by the elitism of this great conversation. The choice of the Great Books in literature, for instance, was based on intellectual privilege that silenced the knowledge of the other, the poor, the marginalised and the underrepresented in our society. Who these great minds were became a cultural-political quagmire, because the choices were always conformist, and hence, prejudiced and arbitrary. Evidently, the Great Tradition of English writing formulated by FR Leavis (Leavis 1950, pp. 1-27) remained biased because its elitism and masculinity 
disallowed dissonant voices. Josef Conrad was considered better than Emily Bronte, although those arguments merely dismissed women's writing (pp.1-27). Though the selection was based on liberal humanism, it merely foregrounded European values and tradition causing the silence of native knowledge. Though knowledge or knowledge-making was never innocent, the true sharing between intellectuals seemed grossly undemocratic. Only an elite few expanded and fostered the great conversation. They remained partial and partisan, although spouting liberal values. Many years after this shackling initiative, Mortimer Adler (1990) recaptured this spectacular failure only to re-inscribe its insidious elitism:

What binds the authors together in an intellectual community is the great conversation ... we find authors listening to what their predecessors have had to say...They not only harken to the thought of their predecessors, they also respond to it...(1990, p. 28)

The intellectual community, its commentary, its inheritance, its critiques - all turned imperial and gendered, valorizing only select writers and thinkers. Some, like prize committees, co-opted dissidence, into this esoteric system. Unlike the earlier culturalpolitics of exclusion, there entered the politics of co-option, of including to silence troublesome voices of alterity. Thus, another kind of cultural capital (Bourdieu, 1986, pp. 241-58), emerged that searched to iron out difference.

So, it was with Bob Dylan. Dylan was the thorn in the flesh of the establishment for he called their bluff all the time. His signature song, "Blowin' in the Wind" (1963), attacked the establishment:

"Yes, and how many ears must one man have.

Before he can hear people cry?

Yes, and how many deaths will it take 'til he knows

That too many people have died?" (1963/2020 retrieved)

He represented folk counter-culture and was an unabashed social critic. He sang on the famous March on Washington, when Martin Luther King spoke of "I have a Dream". When dominant 
McCarthyism demanded silence, Dylan rejected it and continued his protest singing. He attacked white racism and its impervious nature; there were many ballads that indicted white lynching of black folks and illicit sentencing of African-American peoples. Yet he refused to be slotted or straitjacketed as protester; he sang at every sit-in against nuclear power, every march for equal wages and against discrimination. He remained a "troubadour" (Macrum, 2005) an alternative to both establishment and its opponents, resisting binary opposites (Drier 2011). However, Dylan kept changing, from protester, to folk musician, to Christian, to poppsychedelic artist, becoming the eternal contrarian (Fluxman, 1991, p. 91-111). He represented 'alterity', a certain thirdness, a neither here-nor-there location (Ashcroft et al., p. 204), as an occupant of the third space.

But Dylan, shocking all, accepted the Nobel, despite his usual reluctance to accept awards (Drier, 2011). Dylan's journey to the Nobel was interesting. His career's first phase, often called the political phase, ended in disillusionment concerning "art being tied to political protest" (p. 95). With "Another side of Dylan" (p.94) Dylan became "genuinely critical"(p. 95) and argued against a social system based on "individualist principles"(p.96) which caused violence and kept people unfree. Dylan then moved into self-reflexivity - "why an artist cannot be...a cultural critic" (p. 96) - which became central to his discography. Soon he turned to Christianity questing after "transcendental truth" (p. 104), making him different from but acceptable to the reigning deities of the establishment. He was tracked down; he sent in his Nobel acceptance speech; he valorised both pop-culture and established literature; Buddy Holly and Homer, to the satirical Don Quixote and the theological Moby Dick, to grand adventure, to limitless horror and to swaggering travel (Dylan, 2016, Nobel Lecture): Bob Dylan was on his way to co-option, as his resistance was canonised. Such was the enigma of alterity wherein resisting difference was coopted into the establishment. Indeed, the subject that Dylan is today, emerges from the other, that he once was. 


\section{Achebe and 'girls at war'}

Often perceived as the father of African English fiction, Chinua Achebe became famous for his stories of Africa. For many centuries, African society and its culture were represented from highly Eurocentric perspectives of civilisation, constructed by the scramble for Africa and the imperial high-noon of the 1880's. Though Achebe's writing sought to set the record straight, he also critiqued Africa's own pitfalls: particularly its civil wars, sexual violence and post-colonial tyrannies. Girls at War and Other stories (1971/1991), a collection of short stories, represented this critique. The titular story narrated the disaster of Biafran war in the South with all its disease, shortage, checkpoint culture and tragic romance

The Biafran republic seceded from united Nigeria after British decolonisation. The majority Igbo community was Christian, while the North was majority Hausa-Fulani and Muslim; the south-West was Christian too but was majority Yoruba. Just six years after independence, a military coup by young Igbo officers led to secession and civil war. While the Northern armies fought for reunification, the Igbo militias struggled for a separate homeland. Much heart-ache, anger, sometimes deep resentment and frustration apart, the war divided ethnic communities internally as well. Check-point-charlie regimes, commodity blockades, airstrikes and international aid-smuggling - all inflected the Biafran war.

The story of Gladys and Reginald unfolded in these highly volatile conditions. Gladys was a Biafran revolutionary checking even Reginald's car-trunk, for smuggled goods, despite his officiating in the Ministry of justice; though irritated, he permitted the search; Gladys responded: "Sorry to delay you, Sir. But you people gave us this job to do" (Achebe, 1971, p. 102). It made Reginald believe truly in "revolution" (p.103), for these were women militias, committed to their imagined homeland. Although the civil war was about oil and agrarian resources, the ideology of freedom, the hope of self-governance, and the possibility of peace ran strong among youth. But during the "blockade" when shortages, starvation, death and despair haunted the people and "girls became girls and boys, boys" (p. 104), Gladys became that "attractive girl" - stopping his 
car for a lift into town-all decked up and "wearing a tinted-wig, a very expensive skirt and low-cut blouse. Her shoes ...must have cost a fortune" (p. 106). She seemed mistress to some "well-placed gentleman" making money on the war (p. 106). Refugee camps, international aid, rations, protests, and air-strikes - all combined to make the Igbol and a fearful desperate place, returning revolutionaries to the ordinariness of assimilation.

The tale narrated a tempestuous romance, adulterous, secret, uncertain, but profoundly respectful; yet romance turned tragic when an air-raid killed Gladys. But more tragic was another trajectory: how revolutionary youth were absorbed into the routines of expected sensuality; from "militia girl" to "beauty queen", a rite of passage that bore out "war-sickness" (p. 109). "[W]ithout bunkers" everywhere was dangerous (p. 108); worse if one was a young woman. Generals and officers made quick profits and won favours, from international organisations and threw parties, in "the swinging town" of "Owerri", where "gay bachelors" lived (p. 108). The "faith in the struggle" was "betrayed" by the "frivolities" people "clung on to"(p.108). The spirit of opposition and radical transformative change slowly eroded; the wastefulness of war played difference into absorption. Everybody was "out to have a good time" (p. 108). "Big men" exploited the War, "trading with the enemy", "selling relief"... "swindling the government" and getting "foreign exchange" (p. 109). War then was not about freedom but about profit. Alterity as opposition was absorbed into assimilation by the socio-political order. Change became elusive as difference ended in assimilated silence.

Reginald's conversation with Gladys before her death indicted women for their sexual expressivity. He second-guessed how her friend, Augusta would "come on arms plane loaded with shoes, wigs, pants, bras, cosmetics"..."sell them and make thousands of pounds" (p. 111).

Gladys' response, "that is what you men want us to do" (p. 111), exposed the sexist consciousness, Reginald represented. He urged her however to become someone progressive:

...that girl in khaki jeans who searched

Without mercy at the check point?.. 
That is the girl. I want you to become again...(p.112) Gladys responded in despair:

That time done pass. Now everybody want survival. They call

It number six... Everything all right. (p.112)

After his night of pleasure, Reginald contemplated on the state of his homeland. Gladys' experience mirrored his "society that had gone completely rotten and maggoty at the centre" (p. 116).Men traded young men for foreign exchange and "looted goods and cigarettes behind enemy lines"; "contractors" received "piles of money daily for food...never delivered to the army" (p. 116). Even the young broken man, walking on crutches, that Reginald met, spoke with pride about his loss in "Azumini". There was hope yet; and Reginald promised "due reward when it is all over" (p. 119)

This experience exemplified the inability to sustain political commitment. Steadfastness waned because of the weariness of war, weakening resistance into survival, and coercing alterity into subjugated consent. Oppressive socio-political conditions often absorbed revolutionary difference into the mainstream, hegemonising alterity into social and political stagnation. One more enigma indeed, when the radical politics of alterity was stifled into consenting assimilation and absorption.

\section{Dreamtime Stories: The Aboriginal Creation Myths}

Creation myths were also origin-stories. They were pre-historic, belonging to "mythos" (Armstrong, 2009). Their telling functioned as explanatory paradigms for culture. They were anthropomorphic and inspired insights into culture as "the whole way of life" (Williams, 1960a, p. xiv). These myths deified places and objects in the natural world. Sky, Earth, Sun, Moon, Wind, Fire, Water - all were worshipped; while men and women became ancestral Gods and Goddesses, according to their lineage. Therefore, these stories constituted an episteme of difference that enabled seeing the world, self and identity differently.

The Australian aboriginal rainbow serpent stories carried such epistemic possibilities. The Rainbow Serpent was bi-sexual and 
slept in the ground. When it awoke, it produced the frogs and other creatures of the earth and water. The earth then was flat and the Rainbow Serpent meandered through the land, leaving marks in its path, which became the lakes, the rivers, the geysers. It created rock-regions such as the "Ulhuru" (Ayers Rock). It created the male Almudj, destroyer and protector, who lived under the waterfall. The Rainbow serpent punished people when they erred (Australian Myths, 2020).

The myth of the seven sisters, escaping from Wati-Nehru, a man about to rape the oldest created trees, caves, and the firmament of stars. The sisters became the Pleiades, while the pursuing lover, Orion (Australian Myths, 2020).

The Tagai people of the Torres Straits and islands were seafaring and told stories about waters and stars. Tagai went fishing with twelve crewmen, also known as Zugubals-heavenly spirits, who became men. They could not find fish. So Tagai wandered through dangerous reef to get some. The twelve crew-men, meanwhile, grew warm and thirsty; they drank up all the water, including Tagai's share. On his return, Tagai, infuriated and insulted, killed them and hanged them in the firmament as Usal and Utimal, the Pleiades and the Orion. Tagai himself controlled the stars, mediating between land and water; in early astronomy the stars' movement told people when to plant, till, gather mushrooms and fish. These tales explained the complex ecology of land and water and defined natural law.

Natural law preserved land, sea, sky and people for all eternity. Curses would fall if nature was harmed. Thus ecological diversity became the source and principle of human culture. It differentiated ethnicities, federated nationalities, and resisted centralism. People were different, just like their ecology. Preserving difference was spiritual, natural and material, its cosmopolitanism, more deeply sustainable for the species-centric nature of culture. Simplicity and difference reigned supreme as animism's totems and taboos commanded generic equality. But foreign invaders - particularly British imperialism-performed genocide on the ethnic aboriginals of Australia (Hamarcher \& Norris, 2011). 
European discovery projects and their stories violated native communities during settlement. James Cook's landings on Botany Bay created a penal colony with Irish and Scottish prisoners. Simultaneously, other free-loading settlers organised indentured labour of aboriginal natives, fought unrighteous and violent wars, stole native land and unleashed the worst reprisals upon the aboriginals, including poising their watering holes and capturing their women. That apart, the penal colony also produced bushrangers-criminals who dodged prison and the colonial government. They looted both settler homesteads and aboriginal homelands with impunity. But the bush rangers became nationalists, iconic heroes, demanding a separate nation and independence from Britain. The settlement of Tasmania and the Torres Island Straits forged an emerging creole population, after much inter-mixing. This creole community suffered as the "stolen generation" (Read, 1981/2011, p. 1) of Australia. For the indigenous community, colonization caused nightmare, while pre-colonial Australia remained "Dream-time" (Encyclopaedia Britannica, 2018).

British colonialism and its cultural imperialism sought to homogenise a multi-ethnic society. The British employed ideas of modernity and civilisation, and primitivised indigenous peoples. The colonial and later the Federal Governments forcibly took away aboriginal children from their homes to civilise them in European ways. These children were trafficked into mission stations, government centres, and private industry, only to be lost forever to aboriginal parents. They ended up as domestic servants or station hands; they earned low wages and lived like enslaved populations. The "Stolen Generations" became menial labour for post-colonial Australia (pp. 1, 10 \& 11).

Yet the aboriginal people persisted but the retuning children were forced back to mission stations under new regulations. The general psyche was hurt and anguished hurtling them into crime, suicide and dysfunctionality.

This psycho-social malaise of the Stolen generations actually represented the struggle with creole and aboriginal difference. Their alterity was obliterated by colonial racism and coerced into imperialising civilisation. Their past, their oral culture, their 
stories-all lost to civilisation as they entered a neither-norexperience, that was nowhere. In being nowhere the aboriginal and the creole marked and sustained difference.

\section{Mesrop Mashtots and the Armenian Alphabet}

This narrative concerned Biblical translation in the period of antiquity and deserved accounting as a narrative of identityformation.

Translation from one language to another, perceived as a transaction between cultures, was regularly described by the phrase, lost in translation. That is, meaning particularly was apparently lost to guest-languages or receiving cultures, because neither native sensibilities nor original style, was replicable elsewhere. But receiving/guest languages and cultures, could profit from new stories and their polyphonic potential, (Bakhtin, 1984, p. 6) because both language and culture would be transformed back and forth by transacting cultural difference.

Narratives travelled-and continues to do so, even now-in translation but suffered the cultural-politics of language hierarchies, which created cultural superiority for conquering languages and cultures. Yet translations expanded homelands

(Goethe, 1986, p. 227) liberated meaning (Spivak, 1999, p. 163) deployed ideology (Crossan, 1992, p. 272) and refreshed episteme (Foucault, 1966/1989, pp.xi-xxvi). These features of translation came together in the gothic bible and the famous Bishop Ulfilasthe barbarian bishop, and "Little Wolf", who brought to Scandinavian Goths the bible and its teaching in the war-torn faultlines between 300 and 400 CE (Pakis, 2008, pp. 277-304).

Ulfilas was an Arian and forged peace with the then Emperor Valens. But the Roman legions pillaged the Goths, on their Danube crossing, earning their wrath and contempt. The Goths became Christian but soon they consolidated power to overrun the Holy Roman empire, establishing their superiority over Europe.

Ulfilas' Arianism rejected Jesus as co-eternal with God. He was equal in essence but was only after God (Pakis, pp. 277-304).The Arians perceived God, Man/Woman and the world differently and 
opposed prevailing Christian dogma. Ulfilas altered the translation, particularly the lineage of Jesus, to prove Jesus' secondary status, just as in pre-Christian religions. Thus, the Gothic biblical translation underpinned animistic episteme, backed Arian ideology, and contested doctrinaire hermeneutics. It also expanded the idea of Gothic homeland and nationality, when Ulfilas produced the Gothic script, the alphabet, for the biblical translation. Thus, the four features of translation conjoined to formulate the site of identity politics and cultural difference (Dunn, 2012, pp. 1-23).

But it was in Armenia, beyond ancient Persia, in a different language and ethnicity that Mesrop Mashtots' story would unfold. Biblical translations and their trajectories mediated the birth of Armenian writing and nationality. At this juncture, Iranian Oikumene-meaning ecumenical-and Byzantine civilisations collided in intermittent cultural struggle but the Armenian language, its ethnicity, culture and identity were extracted from this context (Dadoyan, 2011, pp. 13-18).

Between the late $3^{\text {rd }}$ and early $4^{\text {th }}$ Centuries CE, Armenia remained a battleground, not just of empires but also of cultures, conflicted between Byzantium and Persian civilisations. The conflict was marked by cultural-politics between East and West. Christianity was varied and the triangular relations between church, palace and people caused wars and retribution. Armenia was a hostile vassal kingdom within the Roman/Byzantine and Persian/ Sassanid empires. Armenia converted to Christianity, but its faith was highly politicised. Besides, plurality posited its own triadic confusions: Syrian-orthodoxy contested Persian and/or Byzantine Christianity (p. 14). Jesus' messianic re-incarnation and Virgin birth were central to this conflict; most believed that Jesus' birth was natural; he became messianic and was deified because of baptismal adoption. This was unacceptable to both Persian and Byzantine Christianity (p. 14). As time progressed, the Armenian church was also influenced by Arianism, that suspected the very divinity of Jesus and deified him in hierarchies of pagan theology. Since faith was political (p. 14), there was constant fear over whether religious belief was turning towards east or west and by implication whether politics and law inclined towards Persia or Byzantium. Partitioned culturally and politically between Roman-Byzantine Christianity 
and Persian-Iranian Oikumene, Armenia struggled between Roman Christianity and pagan worship (p.14).Moreover, religious appointments, Church leadership, particularly the Catholicosequivalent to cardinals - acquired cultural-political power causing dissent and dissidence, if not outright rebellion. The Catholicos' position became hereditary (p.16) and often created parallel powerstructures detrimental to the political state. Into this quagmire between Iranian Oikumene, Byzantine logos and Armenian selfdescription arrived Mesrop Mashtots, bishop and linguist, who rewrote Armenian history by mobilising language and identity through religion and its texts.

Mesrop Mashtots, born into nobility, abandoned his aristocratic lifestyle and chose a life of sacrifice and austerity, of prayer, meditation and the study of scriptures. He had learnt Greek and Persian, the languages of high civilisations that marked the "eastwest couple"(Zekiyan, 2005, p. 232)of world culture then. Having encountered Persian-Iranian Oikumene (p. 231), the good bishop attempted to create an Armenian "Christian Oikumene" (p. 239)and an Armenian identity different from the Persian/ Iranian or Roman/ Byzantine Oikumene. He also searched for an independent Armenian nation.

Commissioned by the then King and the Catholicos, Mashtots travelled deep into Armenia to proselytise a confused people to the Christian faith. Near the Goghtn and the river Araxes, roughly around contemporary Azerbaijan, the bishop met with great success, converting semi-pagan and pagan communities into Christian faith. Heused Greek or Syrian or Persian scriptures but struggled to communicate the great mysteries of the faith to consciously pagan and heretical congregations, waiting to return to Persian Sun-worship or Byzantine ritual. Therefore, he chose to give Armenians an alphabet, which could then disseminate the deep insights of biblical traditions in their own language. With help from his Prince, the Catholicos, Sahak Partev - or Isaac, the GreatDaniel from Mesopotamia and Rufinus of Samosata, they adapted the Greek script into an Armenian alphabet. Mashtots successfully translated the bible into a tongue hitherto unknown. In the moment of biblical translation, the Armenian language was born, (p.239) perhaps in $404 \mathrm{CE}$, and with it arrived Armenian national identity. 
The first verses of the Book of Proverbs were the first words ever written or translated in the Armenia language:

To know wisdom and instruction; to perceive the words of understanding (1:2).

With Mashtots encouragement and subsequent cultural motivations, Armenian language produced a robust literary and artistic culture that travelled back and forth between Persia and Rome, re-shaping their Oikumene through Armenian aesthetics and Christianity. A language was born and with it a nationality, deliberately alternative and consciously differentiated from the other ethnicities of the region. In other words, there was Armenian alterity by separation, which was certainly a separate culture-not yet a separate state-rebelling against other authoritarian civilisations. Though Vardan Mamikonian, the Armenian Commander, lost to Persian-Sasanian forces in $451 \mathrm{CE}$, the emergent Armenian self, rooted in Armenian language and invested in Christianity created an alternative Oikumene, that fought its way to the treaty of Nuarsak, when all Armenia received both religious freedom and political autonomy. Christian faith and the Armenian language won Armenia its freedom and identity, but also erected their uncompromising alterity(p.238).

\section{Conclusion}

It is clear from the preceding narratives that alterity as otherness is a critical paradox. It is fluid and stable simultaneously, because othering, for all its dialectics, splits from the idealised subject and conjoins with its differentiated self at once (Lacan, 1977).This process of splitting from and re-joining autonomous subjectivity is named appropriation(Ashcroft et al,p.6). The politics between the popular and canonical, between the resisting and the authoritarian, forges differing forms of appropriation. The case of Bob Dylan represents many splittings and many re-joinings: from resisting Folk artist to Nobel laureate; from civil rights activist to Christian spiritualist; from hermit-like recluse to public icon; from antiestablishment to academic great-herein lies the many co-options which for all the difference, lives loosely between authority and difference. The alterity of such a condition, recognised as 
ambiguity, truly remains fluid and momentary. Thus resistance, if that is alterity, lives in the fulcrum of flux, moving into and out of subject-formation. So, Bob Dylan, the resisting other, becomes the social subject.

With Achebe's Gladys and Reginald, the revolutionary others become adapting subjects, absorbed into their subjectivity by the politics of accommodation, caused by un-reflexive revolutionary tendencies that subsume great ideals and oppositional politics. The tragedy of cultural-political assimilation becomes intellectually inevitable as both Gladys' violent death and Reginald's ideological prevarications are. The failure of purpose, political absurdity, tragic romance and ambition to equality-all are lost to facile accommodation, inchoate frolic and unscrupulous degeneration, which grudgingly repeat assimilation into authority. The subject of desire (Gladys) in the story is also the object of war and violence. Biafran otherness fluctuates between tyrannical control and personal freedom, as the suffering other mimics the authoritarian subject to enact otherness. The other assimilates the sovereignty of the subject, as Reginald both suspects and loves the Gladys, he admires; manipulates authority for goods and services, though for charity and goodwill. Gladys' revolutionary attributes taper into incongruent desire, uncertain and dissipated. From being the resisting woman as other, she becomes the object of desire as political consciousness degenerates into routine getting-by. The other of difference, the object of power, assimilates into the undifferentiated subject of violence.

Both the co-optative subject and the undifferentiated other, namely Dylan and Achebe's characters, are enigmas of coercion. Folk artists becoming aesthetic geniuses and revolutionaries becoming tyrants-both underscore the coercive but subversive habit of cultural-political hegemony, which promotes consent, either by ambition or by fear, establishing varied subjectivities of power.

The creation myths imagine the Australian continent differently from other creation stories. The killing of dragons, the presence of a superior female force and the birth of nature and the creation of man/woman - all are absent in the aboriginal system of creation; hence, Australian-aboriginal tradition proposes alterity as identity. The politics of difference, mediated by settlerdom, colonialism, 
indentured labour, bushrangers, and the condition of forgotten generations, imperialises Australian subjectivity and enforces an otherness onto a subject-position. That is, the subjectivity of aboriginal communities is stripped off into subjugation by the violence of colonialism. This constitutes the next enigma of alterity in which the Australian ethos is reduced to the subjugated other. The subject is coerced to become its object. The aboriginal tale is replaced by stories of struggling white settlement, penal colony, settler battles bushranger authority, marginalising imagined origins of indigenous peoples. Finally, in the stealing of creolised children for domestic and industrial labour, indigenous subjectivity is othered. Thus difference shifts from aboriginal origins to white settlement. This historical replacement of origins is cultural violence. But the aboriginals, despite such imperialisms assert their alterity through their orature, their resistance to homogenising centralism, and above all through reminding memorials of cultural ritual and festival.

With Armenia, the birth of the Armenian script defines alterity, otherwise subsumed in the East-West coupling (Zekiyan, p. 232) of Persian-Byzantine identity struggles. In such a conflicted context, Armenising its social and cultural order in Christian terms produces an alternative discourse; and a new language and its accompanying script forges an assertive alterity. In other words, the power of discourse and the discourse of power, particularly conjoin to subsume Armenia within East-West dialectics. In extracting a language from cultural imperialisms, nationality as difference arises, enabling the subjectivity of otherness, and emphasising separation over sameness. Thus the emerging Armenian nationality draws from the translation of biblical texts into a self-defining language. This new language and its accompanying nationality emancipate Armenian identity from an older cultural order. A new people are born from the mainstreamed, settled, conquering social order. Alterity emerges as the otherness of separation.

Cultural hegemony subsumes difference, co-opting and assimilating identities and otherness - in Dylan's and Achebe's stories-to form the first cluster of enigmas, while linguistic separation and alternative mythologising-as in Armenian nationality and aboriginal mythology - prompt other complexities. 
It is discourse as both hegemony and counter-hegemony that produce these fluid enigmas. Hence the discourse of resistance could degenerate into authoritarian subjectivity as silenced languages could be extracted into progressive alterity. Hence every discourse subsumes its own counter-narrative, making mobile both subjectivity and alterity. Hence any language, story and song enforce silence and empower speech, control and disseminate difference, order and dissipate assimilation, split and conjoin alterity.

It is this unstable nature of both difference and alterity that demands recurrent self-reflexivity from both the subject and the other. Alterity's mobility is its instability, but also its located possibility. It is in this sense, that alterity as fluid and stable becomes an enigma of cultural-politics.

Alterity then is temporal, i.e. only true for a time; it is unstable, as an idea, and fluid in meaning. Therefore, it remains a shifting ontological question and an epistemological complexity.

\section{References}

Achebe, C. (1971/1991). Girls at war and other Stories. New York, NY: Anchor Books/ Random House

Adler, M. (1990). The great conversation revisited. The great conversation: A Peoples guide to great books of the western world. Chicago, Illinois: Encyclopaedia Britannica Inc.

Armstrong, K. (2009). Metaphysical mistake. The Guardian. Manchester/ London, England: Guardian Media Group.

Ashcroft, B, Griffiths, G., \& Tiffin, H. (1989). The empire writes back: theory and practice in post-colonial literatures London/NY, New York: Routledge.

---Australian creation myths. Retrieved from http:// www. crystalinks. com/dreamtime.html

Bakhtin, M. (1984). In C. Emerson (Ed. and Trans). Problems of Dostoevsky's poetics, Minneapolis: University of Minnesota Press

Bhabha, H. K. (2004). The location of culture. London/NY, New York: Routledge.

Bordieu, P. (1986). Forms of capital. In J. Richardson (Ed.)., Handbook of theory and research for the sociology of education. Westport, CT: Greenwood. 
Crossan, J.D. (1992). Kingdom and wisdom. The historical Jesus: The life of a Mediterranean peasant. New York, NY: Harper One/Harper Collins.

Dadoyan, S. B. (2014). The Armenians in the medieval Islamic world: paradigms of interaction: seventh to fourteenth centuries. Routledge.

Drier, P. (2011). The Political Bob Dylan. Retrieved from https://www.dissentmagazine.org/online_articles/the-political-bobdylan

Dunn, M. (2012). Intuiting Gods: creed and cognition in the fourth century historical reflections / réflexions historiques. NY: Berghahn Books.

Dylan, B. (1963). Blowin' in the Wind. Retrieved from http:// www. metrolyrics.com/blowing-in-the-wind-lyrics-bob-dylan.html. Acc. Jan 27

Dylan. B. (2016). Nobel lecture. Nobel Prize in literature 2016. Retrieved from https://www.nobelprize.org/ prizes/literature/ 2016/ dylan/ lecture/

Editors. (2016). The dreaming: Australian aboriginal mythology. Encyclopædia Britannica London, England: Encyclopædia Britannica, Inc. Online.

Ellis-Petersen, H., \& Flood, A. (2016, October 13). Bob Dylan wins Nobel prize for literature. The guardian.

Fluxman, T. (1991). Bob Dylan and the dialectic of enlightenment: critical lyricist in the age of high capitalism. Theoria: A Journal of Social and Political Theory, (77), 91-111.

Førland, T. E. (1992). Bringing It All Back Home or Another Side of Bob Dylan: Midwestern Isolationist. Journal of American studies, 26(3), 337355.

Foucault, M. (1973). Preface. The Order of Things: An archaeology of the human sciences. 1966. New York: Routledge Classics.

Foucault, Michel (1966/1989) Preface.The order of things: An archaeology of the human sciences London/ New York, NY: Routledge Classics xvixxvi.

Goethe,W. J. (1986). In J. Gearey (Ed.), Essays on art and literature: Goethe's collected works. New York: Suhrkamp.

Hamacher, D. W., \& Norris, R. P. (2010). Australian Aboriginal geomythology: eyewitness accounts of cosmic impacts? The journal of astronomy in culture.

Heard, R. (2016). Introduction to the New Testament in Ted \& Winnie Brock (materialled and Ed) for Religion-Online. New York, NY: Harper \& Collins.

Hofweber, T. (2018). Logic and ontology. In E. N. Zalta (Ed.)., The Stanford Encyclopedia of philosophy. Retrieved from URL:<https:/ / plato.stanford. edu/archives/sum2018/entries/logic-ontology 
Hutchins, R. M. (1957). Preface. The great conversation. London/Toronto, Ontario: Encyclopaedia Britannica xi-xxvii

Lacan, J. (1977). In A. Sheridan (Trans.)., Ecrits: A selection. New York, NY: Norton.

Leavis, F. R. (1950). The great tradition. New York, NY: George W Stewart Ltd.

Macrum, R. (2005). Dylan, the supreme troubadour. The guardian.

Pakis, V. A. (2008). Homoian vestiges in the Gothic translation of Luke 3, 23-28. Zeitschrift für deutsches Altertum und deutsche Literatur, (H. 3), 277-304.

Read, P. (1981/2006). The stolen generations: The removal of aboriginal children in New South Wales 1883 to 1969. Sydney, New South Wales: Department of Aboriginal affairs.

Said, E. (1979). Orientalism. New York: Vintage Books

Semple, W. H. (1965-6). St. Jerome as a biblical translator, Bulletin (xlviii), 227-43

Sennero, J., \& Scrutton, A. (2016). Greatest living poet Bob Dylan wins Nobel literature prize. World News. London: Reuters.

Shelton, R. (1961). Folk music heard on 12-Hour Show. The New York times.

Solomon, R. C. (2005). Subjectivity. In T. Honderich (Ed.), Oxford companion to philosophy Oxford. New York: Oxford University Press.

Spivak, G. C. (1999). Literature. A critique of postcolonial reason: Toward a history of the vanishing present. Bengal, Calcutta: Seagull Books.

Wa thiong'o, N. (1986). Decolonising the mind: The politics of language in African Literature. London, England: James Currey/ Heinemann Books.

Williams, R. (1977). Marxism and literature. Oxford/New York: Oxford University Press.

Zekiyan, B. L. (2005). The Iranian Oikumene and Armenia. Iran $\mathcal{E}$ the Caucasus, 231-256.

\section{End Notes}

1 See, Solomon, Robert C. (2005), Subjectivity. in Honderich, Ted. Oxford Companion to Philosophy Oxford/New York Oxford University Press, 900.

2 See, Hofweber, Thomas, (Summer 2018 Edition) Logic and Ontology, Edward N. Zalta (Ed.), The Stanford Encyclopedia of Philosophy URL:<https:// plato.stanford.edu/ archives/sum2018/ entries/ $\operatorname{logic}$-ontology/> 